\title{
INTERPRETATION OF RISK ASSESSMENT PROCEDURES AND MANAGEMENT OF RISK FACTORS
}

\author{
Author(s): \\ M. Czikkely
}

\section{Affiliation:}

Assistant lecturer, Climate Change Economics Research Centre, Faculty of Economic and Social Sciences,

Szent István University, Gödöllö

Email address:

czikkely.marton@gtk.szie.hu

\begin{abstract}
The following study seeks to outline a line of thought through which industrial, environmental engineering processes and operations can be evaluated from a risk management perspective. Different risk management models usually consider the risk of introducing a new technique / technology from an environmental and human point of view.
\end{abstract}

\section{Keywords}

Risk assessment, risk factors, process analysis, environment and human risk management

\section{Introduction}

A distinction should be made between the environmental risk assessment of each substance and whether or not relevant environmental concentration values are available for the substance. In the former case, we can only determine the environmental risk by estimation, while in the latter case specific model calculations allow the risk assessment of the substance. In this case, concrete results can also be obtained with respect to environmental exposure (e.g. emission concentrations of industrial technologies, background concentration calculations, spread modelling) [1]. If specific measurement results are available for a particular substance, it is important to perform a critical (and statistical) analysis of the data and to examine the representativeness of the results. In doing so, we can get a realistic picture of realworld environmental emissions and refine our models of environmental emissions and exposure [2]. In the risk analysis of substance emissions, we need to distinguish between point sources and diffuse releases [2]. Local concentration values (PEClocal) are typically determined by point source discharges, which also affect regional concentrations (PECregional) to some extent. Determination of PEC according to Annex III to Directive 93/67 / EEC Annex III, which states that concentrations should always be determined at the local level when assessing environmental risks [3].

\section{PEClocal and PECregional values and prediction of local and regional environmental concentrations predicted}

An important factor in new techniques is the determination of PEClocal concentrations, i.e. the amount of material that is released into the environment from point sources. The PEClocal expresses the expected concentration that occurs at some distance from the source on the day the release occurs [4]. Thus, on the one hand, it gives specific concentration values, but it also provides information that can be considered to a certain extent hypothetical. The determination assumes that the point source is emitted on a regular basis, at defined intervals, so that any release date can be calculated. In some cases, time-dependent concentrations may also be required, which typically need to be considered during periodic releases [4]. PEClocal takes into account degradation and distribution processes. The determination of the PECregional concentration should be performed for larger areas of point or diffuse pollution and reported for the regional environment [4].

PEC values are derived from available measurement results (data), while PNECs are derived from laboratory test data or model ecosystem studies $[1,5]$. The PNEC definition defines a concentration below which a given substance does not pose a safety hazard. Thus, in practice, a relationship can be 
established between PNEC values and contamination limits "B". To determine with certainty whether a given quantity of a substance constitutes a risk to the ecosystem, the environment, the PEC / PNEC ratio must be determined and conclusions drawn. If either of the PECs or the PNECs cannot be determined accurately, a quantitative risk assessment is not possible. According to this, a qualitative risk assessment should be carried out [6].

\section{Estimation of environmental exposure}

A given substance (pollutant) has some effect on the environment throughout its life cycle. Its quantity and concentration may vary, but this change also affects the ecosystem, constantly changing its qualitative characteristics $[5,6]$. Exposure estimation shall be made for all environmental compartments. The following stages of the life cycle of the substance shall be considered during the test: manufacture, processing, storage and transport, use (industrial, commercial, residential) and possible disposal or remediation. An important factor in the estimation of environmental exposure is the volume evolution of past releases $[6,7]$.

These values should also be taken into account because they may cause background concentrations in the environment, i.e. they have a cumulative effect. Exposure levels shall be determined taking into account the measurement data and the results of any model calculations [7]. It should be determined whether the test substance is capable of producing stable or toxic degradation products by biological (biochemical) or abiotic route. If so, their environmental impact should also be considered [8].

In most cases, knowledge and data on biological degradation are only available for aerobic conditions, although anaerobic degradation factors should also be considered in sediment and soil studies. The possibilities of estimating environmental exposures are also strongly influenced by the salinity and $\mathrm{pH}$ of environmental elements [8].

\section{Classification of measurement data at local and/or regional level}

In any risk management process in an environment where specific measurement data is available (and not only calculated through model calculations), classification shall be made at local or regional level. Based on this, it is possible to compare with the calculated PEC values, so it is possible to decide which PEC value we can use to characterize the risk [9]. If the sampling areas in question are not geographically close to the point source for the pollutant, the background concentration of the area shall be reported (PECregional), to which the calculated local concentration values must be added (PEClocal). Purely PEClocal values are obtained when the pollutant concentration values measured in the sampling area are representative of the local character of a given emitting point source.

In the case of contaminated industrial sites, the point of discharge may, where appropriate, coincide with the contaminated site [5,9]. Sampling must take into account the different behaviour of the pollutants, i.e. changes in concentration to physico-chemical and biological effects [10]. In the case of substances produced in large quantities, which may have environmental risk characteristics, it should be borne in mind that use may vary over time, and thus environmental emissions may also be affected accordingly. In this case, all possible emission values must be added at the local level since emissions change over the life cycle of the substance. In the case of a regional risk assessment, the total emission values for all environmental compartments shall be added over the life cycle of the pollutant.

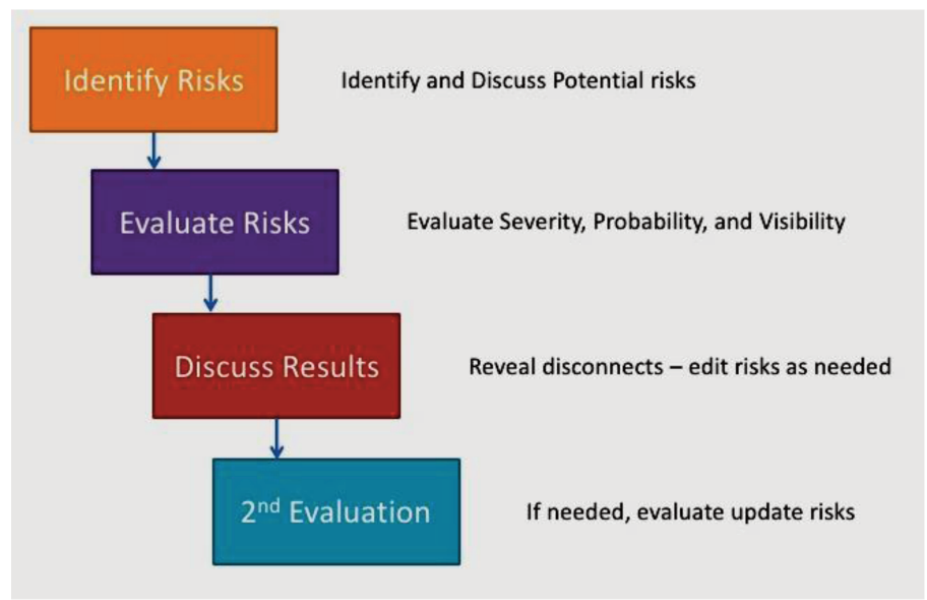

Figure 1. The risk assessment process [11] 
Regional environmental concentrations should always be reported in relation to local background concentrations [6].

For long-lived substances that can be measured over several years (for example, chemically bound pollutants in complex compounds), it should be noted that exposure increases over the life-cycle of the substance $[6,7,10]$. The reason for this is that as the material decays, the bound pollutant is released in ever increasing concentrations. Where emission abatement technologies are used in a given sampling area, their effects shall also be considered in the environmental risk assessment of the pollutant and in the measurement of the quantity (concentration) of the pollutant emitted $[7,10]$.

\section{Risk characterization of environmental elements and aspects}

Exposure to pollutants should be investigated on all environmental compartments since they can affect the entire natural environment in space and time. When calculating local and regional PECs, need to delineate a standardized environment for which we are conducting investigations, as this can interpret our results for a given environmental element [4,12]. Test phases and markings for standard environmental characteristics (based on Jenei, 2016) [12]:

-The density of the solid phase (RHOsolid)

-Density of water (RHOwater)

-Density of air (RHOair)

-Surface waters: suspended concentration (dry weight) (SUSPwater)

-Volume of the solid fraction in suspension (Fsolid/susp)

-Volume of water in suspension (Fsolid/water)

-Volume of solid in soil (Fsolid/soil)

-Volume of water in the soil (Fwater/soil)

-Volume of air in the soil (Fair/soil)

It can be seen from the above that the soil and the suspended material consist of three phases: air (soil only), solid and water. The density of the environmental element is determined by the density of the phases and their volume ratio, as follows (where "element" refers to the phases of each environmental element) [12]:

RHOelement $=[$ Solid element $\cdot$ RHOsolid $]+$ [Freshwater element $\cdot$ RHOwater $]+[$ Air element .

$$
\text { RHOair] }
$$

From this equation, it can be concluded that the framework for the data for the whole environmental element is the data series of the three-constituent media, solid, water, and air. In the environment where any of the above three media is not present or is present below the detection limit, the equation must be modified accordingly.

\section{Risk management aspects of wastewater treatment process}

The limit values for surface water pollution and their application are set out in Decree 10/2010. (VIII. 18.) VM. The law specifies what heavy metal concentrations are allowed in surface waters and the concentration (from pollution limit "B") that is considered to be a heavy metal load. In line with the EU Water Framework Directive, efforts should be made to good ecological and environmental status of surface waters.

It is generally accepted if a new water treatment technology can reduce the concentrations of pollutants to below the statutory limits (pollution B limits) and achieving the remediation target value. At the same time, it is important to emphasize that there is a certain competition between water treatment technologies as to which technology can produce the highest possible efficiency.

As for the reviewed literature, important to note that environmental and human health risk assessment is closely related to the efficiency of a given water treatment technology, because the better efficiency of a technique, the better treatment results and the lower concentration of harmful substances decrease the risk of environment and human health problems. By analysing the environmental risk assessment (risk management) process of various pollutants, the accepted basic literature procedures $[13,14,15]$ can also be used in the comprehensive risk management analysis of water treatment technologies presented in the literature [13].

All industrial wastewater treatment technologies have some indirect impact on a natural environment. Analysing this effect in practice means environmental risk analysis, which is usually done with indicator organisms (e.g. Daphnia, fish and fleas) $[14,15]$. From the point of view of the process of environmental risk management, a given technology lasts from the potential emission of pollutants (or the return of pollutants due to insufficient efficiency of the technology), to the accumulation of the environment until the potential contamination is realized [15].

\section{Conclusions}

Environmental and human risk analysis is an important task. We have seen the steps involved in identifying hazardous substances, analysing risky 
discharges, and calculating the level of risk. After that, it is possible to eliminate the risk. Risk analysis and calculation is a multi-step process that is standardized. In our view, one of the major issues is always the identification of potentially hazardous substances. If the potential risk substance is chemically identifiable, the risk management steps will follow. However, if the substance is presented in a chemically complex form, for example in industrial wastewaters, the digestion within the complex form is required as a first step. In this case, the determination of exact risk management steps could follow only the digestion of complex materials.

\section{References}

[1] CARTER, D.A., ROGERS, D.A., SIMKINS, B.J., TREANOR, S.D. 2017: A review of the literature on commodity risk management. J. Commod. Mark. 8: 1-17. p.

[2] SARKAR C., WEBSTER C. 2017: Urban environments and human health: current trends and future directions. Current Opinion in Environmental Sustainability 25: 33-44. p.

[3] ETINAY, N., EGBU, C., MURRAY, V. 2018: Building Urban Resilience for Disaster Risk Management and Disaster Risk Reduction. Procedia Eng. 212: 575-582. p.

[4] NGUYEN, V.N., GINIGE, K., GREENWOOD, D. 2018: Challenges in integrating disaster risk reduction into the built environment - The Vietnam context. Procedia Eng. 212: 316-323. p.

[5] CRAWFORD, M.H., CROWLEY, K., POTTER, S.H., SAUNDERS, W.S.A., JOHNSTON, D.M. 2018: Risk modelling as a tool to support natural hazard risk management in New Zealand local government. Int. J. Disaster Risk Reduct. 28: 610-619. p.

[6] WANG, F., GAO, Y., DONG, W., LI, Z., JIA, X., TAN, R.R. 2017: Segmented pinch analysis for environmental risk management. Resour. Conserv. Recycl. 122: 353-361. p.
[7] CRAIG, C. 2018: Risk management in a policy environment: The particular challenges associated with extreme risks. Futures.

[8] HANSEN, J., HELLIN, J., ROSENSTOCK, T., FISHER, E., CAIRNS, J., STIRLING, C., LAMANNA, C., VAN ETTEN, J., ROSE, A., CAMPBELL, B. 2018: Climate risk management and rural poverty reduction. Agric. Syst.

[9] MEHTA, N., DINO, G.A., AJMONEMARSAN, F., LASAGNA, M., ROMÈ, C., DE LUCA, D.A. 2018: Extractive waste management: A risk analysis approach. Sci. Total Environ. 622-623: 900-912. p.

[10] BODAR, C., SPIJKER, J., LIJZEN, J., WAAIJERS-VAN DER LOOP, S., LUIT, R., HEUGENS, E., JANSSEN, M., WASSENAAR, P., TRAAS, T. 2018: Risk management of hazardous substances in a circular economy. J. Environ. Manage. 212: 108-114. p.

[11] The Risk Assessment Procedures. Basic steps of risk identification.

Web: https://image.slidesharecdn.com

[12] JENEI T. 2016: Leggyakrabban használt kockázatkezelési modellek összehasonlítása (Compare the most frequently used models of risk management). International Journal of Engineering and Management Sciences 1 (1): 1-11.p.

[13] SZÉKELY CS. 2014: A környezeti kockázatok és értékelésük (Environmental risks and their evaluations). Gazdaság és Társadalom (Journal of Economy and Society) 6(1): 15-28. p.

[14] AVEN T. 2016: Risk assessment and risk management: Review of recent advances on their foundation. European Journal of Operational Research 253: 1-13 p.

[15] ANSAH R.H., SOROOSHIAN S. 2017: Effect of lean tools to control external environment risks of construction projects. Sustainable Cities and Society 32: 348-356 p. 